\title{
Cardiac Hemangioma
}

National Cancer Institute

\section{Source}

National Cancer Institute. Cardiac Hemangioma. NCI Thesaurus. Code C45749.

A hemangioma arising from the heart. 